\title{
RESEARCH PAPER \\ Productivity in the Agricultural Sector: A Global Outlook from a Latin American Perspective
}

\author{
Claudio Bravo-Ortega \\ Universidad Adolfo Ibáñez. School of Business. Santiago, Chile.
}

\begin{abstract}
C. Bravo-Ortega. 2021. Productivity in the Agricultural Sector: A Global Outlook from a Latin American Perspective. Int. J. Agric. Nat. Resour. 288-302. Agricultural productivity has been the focus of intense scrutiny since the time of Adam Smith. In this article, we focus on agricultural productivity from two perspectives. First, we provide estimates of total factor productivity (TFP) growth for a panel of 79 countries over a period of approximately 60 years. Second, we investigated the potential determinants of productivity growth, which include infrastructure, macroeconomic variables, and variables related to climate change. We find that productivity varies greatly across countries, with leading countries showing annual agricultural productivity growth between $2 \%$ and $3 \%$. In regards to productivity determinants, we find small within-country effects but significant between-country effects.
\end{abstract}

Keywords: Agriculture, panel data, productivity.

\section{Introduction}

Agricultural productivity has been scrutinized since the time of Adam Smith. To date, most economists assume that agricultural productivity growth is lower than manufacturing industry growth. However, this observation has been repeatedly challenged. Martin \& Mitra (2001) find that agricultural productivity grew more quickly in various developing and developed countries during a significant period in the second half of the 20th century. In this study, we examine the evolution of agricultural productivity over a

Received May 25, 2021. Accepted Dec 16, 2021 Corresponding author: cbravoortega@gmail.com period of approximately 60 years, for which we estimate total factor productivity (TFP) growth for several countries based on the estimate of a translog production function between 1961 and 2017. Secondly, we examine the determinants of agricultural productivity, controlling for infrastructure, macroeconomic variables, and other determinants. The discussion and analysis of our results focus on Latin America compared mostly to developed countries. The long-term perspective of our analysis enriches the partial perspective that more recent research offers for the Latin America. Lastly, the inclusion of more than 70 countries whose data are used to simultaneously estimate idiosyncratic effects provides results with a high amount of external validity that is relevant to policy-making. 
The literature presents abundant evidence that agricultural productivity is a determining factor for aggregate productivity and therefore economic growth. Gollin (2010) finds that in countries with a high percentage of a rural population and limited access to international markets, agricultural productivity is essential for economic growth. Thirtle et al. (2003) find that during the 1980s and 1990s in countries where poverty was concentrated in rural areas, such as Latin America, Asia and Africa, technological changes in agriculture were key to increasing aggregate productivity and reducing poverty levels. This result contrasts with the modest effects of manufacturing productivity in both areas. Lastly, Bustos et al. (2016) and Huang et al. (2004) show that in Brazil and China, the introduction of biotechnology and genetically modified products in agriculture has significantly affected the sector's productivity levels. Restuccia et al. (2008) studied a sample of countries. They found that the employment rate combined with low productivity in the agricultural sector leads to a low level of aggregate productivity in low-income countries (possibly explained by barriers to the incorporation of modern agricultural inputs and in the labor market). Alston et al. (2009) use the United Nations' Food and Agriculture Organization (FAO) data to estimate agricultural production (in metric tons) per worker and hectare for the periods between 1961 and 1990 and 1990 to 2005 , focusing on soybeans, rice, corn, and wheat. They find a significant deceleration in the growth of agricultural productivity, partly linked to a deceleration in agriculture-related research. Lio \& Liu (2006) study 85 countries during the 1995 to 2000 period. They connected agricultural labor productivity with the incorporation of information and communication technologies (ICTs) in the agricultural sector, thus explaining the gap between impoverished and affluent countries by the latter's early adoption of ICTs.

The literature on sectoral productivity shows evidence of persistent productivity gaps between affluent and impoverished countries. Lio \& Lui (2006) show that returns on the introduction of technology in the agricultural sector are higher in affluent countries than in impoverished countries, which may indicate a shortage of factors complementary to technologies in the sector (for example, a substantial base of human capital) that could potentially explain the persistence of these gaps.

According to Ruttan (2002), the study of productivity in agriculture has undergone three stages. Initially, the research focused on measuring indices, such as the output per worker or hectare. These early studies showed large global differences in land and labor productivity. The second stage of research on technical changes in agriculture involved the estimation of production functions between countries and multifactorial productivity estimates. These estimates were created using functions such as the Cobb-Douglas production functions. The results found that the amount of land and livestock resources, machinery, fertilizer, and human capital accounted for approximately 25 percent of the productivity gap between developing and developed countries. Recently, productivity analyses have focused on multifactorial productivity via nonparametric approaches. This research showed a widening of the agricultural productivity gap between developed and developing countries between the 1960s and early 1990s.

Recently, the literature has shown a global convergence in agricultural productivity. In general, according to Alston et al. (2010), agricultural productivity in developed countries (e.g., the United States, the European Union, Canada, and Australia) tended to decelerate in the 1990-2005 period. In contrast, the growth rates of developing countries did not decrease but instead accelerated in certain countries., , Avila et al. (2010) used a Tornquist-Theil index that incorporates employment, land, fertilizers, and tractors as inputs to find that, during the $1990 \mathrm{~s}$, Brazil sustained a 3.4\% growth rate while Colombia's growth rate declined by $1.2 \%$. Fuglie et al. (2007) show a decrease 
in the United States' growth rate from 1980 to 2004, explained by mainly technological change, to which agriculture is more sensitive than other sectors. Using a sample of countries, Fuglie (2008) do not find generalized evidence of deceleration in agricultural TFP but rather deceleration in agricultural investments.

Other authors, such as Coelli \& Rao (2005), estimate the evolution of productivity in relative terms using data envelopment analysis (DEA), consisting of a nonparametric estimation of the production function and the calculation of productivity in relation to a frontier for 93 countries. They found that in the period from 1980 to 2000, productivity grew $2.1 \%$ annually, with 1.2 points explained by a frontier shift and 0.9 points by the convergence toward the frontier ("catchup"), with China showing the highest growth rates. Similarly, Alston et al. (2010) demonstrate an acceleration in Brazil and China. Trindade \& Fulginiti (2015) and Nin Pratt \& Yu (2009) show an acceleration higher than 1 percentage point in Latin America. The latter find that a significant portion of this acceleration is due to changes in economic policy that began in the 1980s and 1990s, with the purpose of attracting investment in research and development, as well as the incorporation of agricultural technology, resulting in the acceleration of agricultural productivity in these countries being largely explained by frontier convergence.

Isakson (2007) reviews several micro-, sectoral, and macro-studies and finds that the main determinants of agricultural productivity are education, health, infrastructure, imports, institutional quality, trade openness, financial development, geographical conditions, and absorptive capacity. Avila \& Evenson (2010) find that years of education and the nutritional status of human capital explain a significant portion of the quality of human capital and its contribution to TFP. Domanska et al. (2014) analyze productivity and its determinants for 27 countries in the European Union between 2007 and 2011 and find low TFP growth with determinants such as the share of farm managers who have completed agricultural education, average farm area, and economic openness (exports over imports), while soil quality, investment grants, and the number of students in agricultural fields were insignificant. Po-Chin et al. (2008) find that in China, specifically in its provinces, the main source of agricultural productivity growth is technical progress throughout the 1990 to 2003 period. In a second-stage regression, it is found that the determinants of technical progress include agricultural tax cuts, public investment in research and development and infrastructure, and mechanization of the sector.

\section{Methodology}

In this study, we will follow Bravo-Ortega \& Lederman's (2004) methodology, which in turn follows Kawagoe, Hayami and Ruttan (1985) and Lau \& Yotopoulos (1989). These authors assume that developed and developing countries show different functions of agricultural production, mainly due to differences in input quality. In our case, we estimate a translog function that can be reduced to:

$$
\ln \left(Y_{c t}\right)=\alpha_{0 c}+\sum_{i} \alpha_{i} \ln \left(X_{i c t}\right)+\frac{1}{2} \sum_{i} \sum_{j} \alpha_{i j} \ln \left(X_{i c t}\right) \ln \left(X_{j c t}\right)+\sum_{i} \gamma_{i} t X_{i t}+\delta_{T} t+\frac{1}{2} \delta_{T T} t^{2}
$$


where $\mathrm{c}$ represents a country index, $\mathrm{i}$ and $\mathrm{j}$ represent factor indices, and $t$ represents a period variable.

As we are interested in the evolution of technical progress, ideally separated by country in accordance with Kim (1992), we added a time trend and its quadratic term to Model (3). Additionally, we interact a trend term with each productive factor, which is the portion of production growth that is not explained by the production factors used.

By differentiating Equation (2) with respect to $\mathrm{T}$, we obtain the TFP growth rate:

(2) TFPGrowth $=\sum_{i} \gamma_{i} \ln X_{\text {ict }}+\delta_{T}+\frac{1}{2} \delta_{T T} t$

In our estimates, we consider six factors that are inputted into the agricultural production function: rural labor, physical capital (approximated by the number of tractors), cropland, grassland, livestock, and fertilizers. The construction of the livestock series followed Seré \& Steinfeld (1996); therefore, livestock is expressed in units equivalent to the number of cows. Lastly, we use the total metric tons of fertilizer that are used each year.

A final note of caution must be stated since the estimates of $y_{i}$ are constant across countries. For example, in country c, the initial endowment $X_{c 0}$, could be low in some cases and greater in others, which impacts productivity growth at the time origin. Suppose there are two countries, $\mathrm{A}$ and $\mathrm{C}$, with the same relative endowments, such as land and labor. However, one country has greater initial endowments than the other country's initial endowments. This proportion is called $\theta$; then, using log transformations, we can express $X_{C 0}=\theta b+A_{C 0}$, where b represents a vector composed of ones of equal dimension to the number of factors. Thus, a reduced formula for TFP growth will be:

(3) TFPgrowth T0 $=\theta \gamma_{x}^{\prime} b+$ TFP growth $_{A 0}$
Therefore, a difference in TFP growth would be shown due to the initial endowment (scale) effect. After correction, the following formula is created:

(4)TFPgrowth $c=\gamma_{x}^{\prime}\left(\ln X_{c t}-\ln X_{c 0}\right)+\delta_{T}+\delta_{T T} t$

This would not require additional estimates but only an intercept shift with respect to Equation (3) that is shown in the tables. The long time span of our dataset, which includes countries worldwide, offers a global perspective that might be difficult to obtain in country-specific studies. As shown below, our discussion of the results focuses on Latin American productivity evolution compared with relevant countries and regions.

Lastly, in most cases, agricultural output and inputs will increase over time, which poses the risk of spurious regression. Therefore, a squared time trend variable has been added to the translog function to explain the variation of output over the squared trend. In the case of our estimations of TFP growth determinants, we consider that TFP growth calculations by construction include a time trend variable; this fact would generate endogeneity by construction if we control for a time trend during second-stage regression. Hence, to reduce the risk of spurious regression, we add time dummy variables to explain a TFP growth variable (i.e., deviations over time means) with the knowledge that our measure of TFP does not result from a spurious relation.

\section{Data}

This work builds a database composed of 60 countries for the 1961-2017 period. To estimate productivity, the data series of the following variables were compiled or constructed: agricultural GDP in constant dollars, irrigated land area, grassland area, cropland area, and total tractors derived from FAOSTAT (online). The latter series is available from 1961 to variable years between 2000 and 2009; therefore, it was 
necessary to estimate the number of tractors based on historical and domestic credit data until 2017. Additionally, the agricultural labor force series was constructed based on FAO estimates by decade, interpolated with annual frequency. The series on livestock in the equivalent number of cows based on the stocks of cattle, lambs, horses, mules, geese, chickens, and ducks were also taken from FAOSTAT. Lastly, the series on fertilizer tons was compiled from the International Fertilizer Industry Association (online).

To study the determinants of productivity, we compiled the series on electricity consumption, telephone lines, and domestic credit from the World Bank; the series on education of the population over 15 years of age, exports and imports over GDP, investment, and productivity related to the United States' GDP from Alvarez (2018); and the series on temperature anomalies from NASA (online'). The finished database contains complete information about 60 countries for the 1961 to 2017 period; however, countries and years may vary for some variables. Table 1 shows the descriptive statistics of the productivity database that accounts for the database's range of years and countries.

Table A1 in the appendix shows descriptive statistics of the variables used in the analysis of productivity determinants that is presented in Section 5, explicitly showing their variation within and between the analyzed countries.

\section{Estimates of the function between production and productivity}

Table 2 presents four estimates of various production functions. In Column 1, we estimate an unrestricted Cobb-Douglas production function, and in Column 2, we include fixed effects per country. The third column shows a translog function without trends, and the fourth column shows the estimate used to compile the productivity growth series that includes trends by productive factors, base and squared trend terms, and fixed effects by country. All estimates were computed by estimating robust standard errors. The significance of the various productive factors is observed in all estimates, including the Cobb-Douglas and translog estimations.

The translog function is a second-order approximation to any production function; therefore, if it has statistically significant terms that are higher than one, more restrictive functions, such as Cobb-Douglas or CES, should be preferred. Considering the above, as well as the significance of the productive factors' quadratic and interactive terms, we prefer the translog specification to estimate the series on agricultural productivity growth. Importantly, one of the properties of translog functions is that it has a specific functional form for each country. In contrast to the Cobb-Douglas functions, which have constant elasticities for each factor and all countries,

Table 1. Descriptive Statistics. Complete Sample (1961-2017)

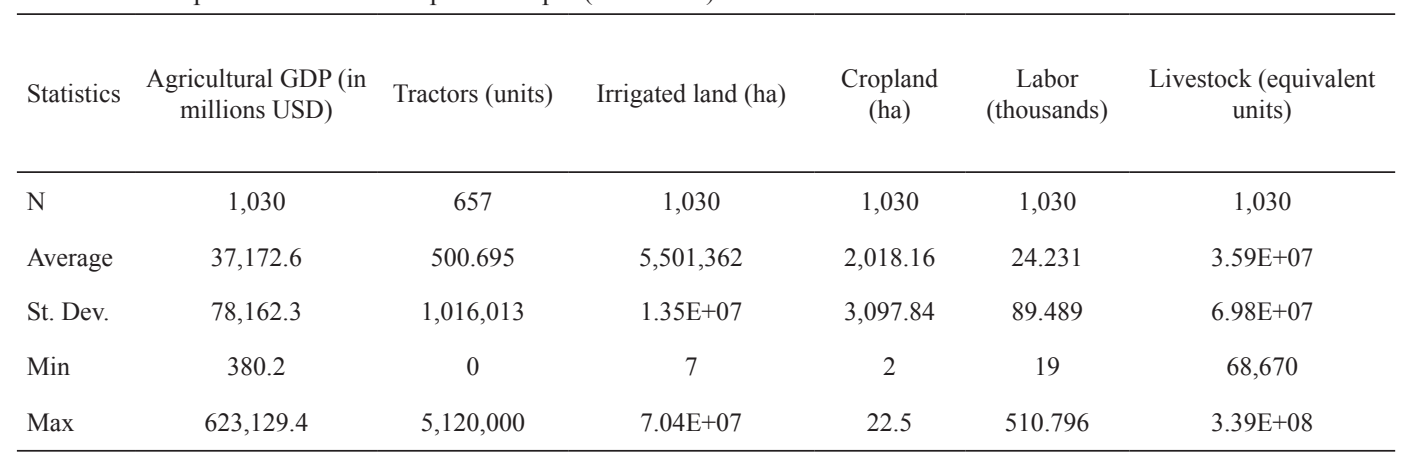

\footnotetext{
${ }^{1}$ https://data.giss.nasa.gov/gistemp/
} 
translog functions have different elasticities for each productive factor and country.

Table A2 in the appendix place the productivity growth estimates in context by comparing the estimates with the output growth per worker, hectare, and total for a selected group of countries in three categories (i.e., high-income, Latin America including high-income countries, and other developing countries), in addition to the arithmetic mean for each list of countries. Column 3 reports the initial endowment effect discussed in the methodology, and Column 4 shows the net growth of TFP.

Latin American countries have experienced an average agricultural GDP growth of $2.8 \%$ per year between 1961 and 2017, while its productivity grew at a rate of $1.5 \%$ and a net of 1.9 in the initial endowment effect per year. Argentina and Brazil have the highest annual productivity growth rates of $1.9 \%$ (net $1.9 \%$ ), followed by Chile with a growth rate of $1.7 \%$ (net $1.9 \%$ ) and Mexico with an annual growth rate of $1.7 \%$ (net $1.9 \%){ }^{2}$ Brazil's agricultural GDP grew by $3.7 \%$ annually, Mexico's agricultural GDP grew by $3.0 \%$ annually, Chile's agricultural GDP grew by $2.5 \%$ annually, and Argentina's agricultural GDP grew by $2.3 \%$ annually. For the listed countries, the net of initial endowment TFP growth is $1.9 \%$, which is $0.4 \%$ greater than in the country where this effect is not computed.

Latin America's performance is acceptable compared to high-income countries. Indeed, it is similar in terms of the net of initial endowment productivity. Canada, Italy, and Spain have the highest productivity among the high-income group with annual productivity growth rates of $2.9 \%$ in Canada (net 1.7\%) and $2.5 \%$ in Italy and Spain (net $2.2 \%$ and net $2.3 \%$, respectively). The
United States and France have the next highest annual growth rates of $2.3 \%$ (net $1.8 \%$ and 2.0 , respectively). In contrast to Latin America, output growth is lower in high-income countries, with rates of $1.7 \%$ in Canada, $1.9 \%$ in Spain, $0.6 \%$ in Italy, $0.4 \%$ in France, and $1.6 \%$ in the US. Output growth lower than productivity growth should not be surprising since it is consistent with an agricultural sector that does not emphasize labor, total investment, or total GDP, as argued by Chenery $\&$ Syrquin in the 1970 s. This result is consistent with an "expulsion of productive factors" from the agricultural sector to other sectors of the economy in developed countries. The inclusion of the initial endowment effect closes the gap across countries. The performance of Latin America is significantly better than its performance without this effect.

Table A3 in the appendix shows estimated elasticities by productive factors based on Column 4 of Table 2 alongside the returns to scale for a selected group of countries and averages of three groups of countries and the world. As summarized in Table A3, labor and machinery elasticities fall ${ }^{3}$. The latter may be because the FAOSTAT tractor series is discontinued and was therefore predicted based on historical data. Similarly, the FAOSTAT employment series is also poor in quality; thus, employment figures were interpolated based on FAO decade forecasts. However, the production scale is consistent with what is observed in reality, with China, India, Brazil, Mexico, the United States, and Argentina having the highest returns to scale.

\section{Determinants of productivity}

In this section, we explore the determinants of agricultural productivity growth based on the esti-

\footnotetext{
${ }^{2}$ Riveros (2019) finds an average of 1.1\% growth in Chile during the last two decades and a deceleration not shown in our results. In contrast, our results are consistent with the literature reviewed in the introduction that finds an acceleration in productivity within developing countries.

${ }^{3}$ In Chile, Riveros (2019) also observes a steep drop in the capital/GDP ratio after the 1990s for the forestry and agricultural sector.
} 
Table 2. Cobb-Douglas and Translog Production Functions (1961-2017)

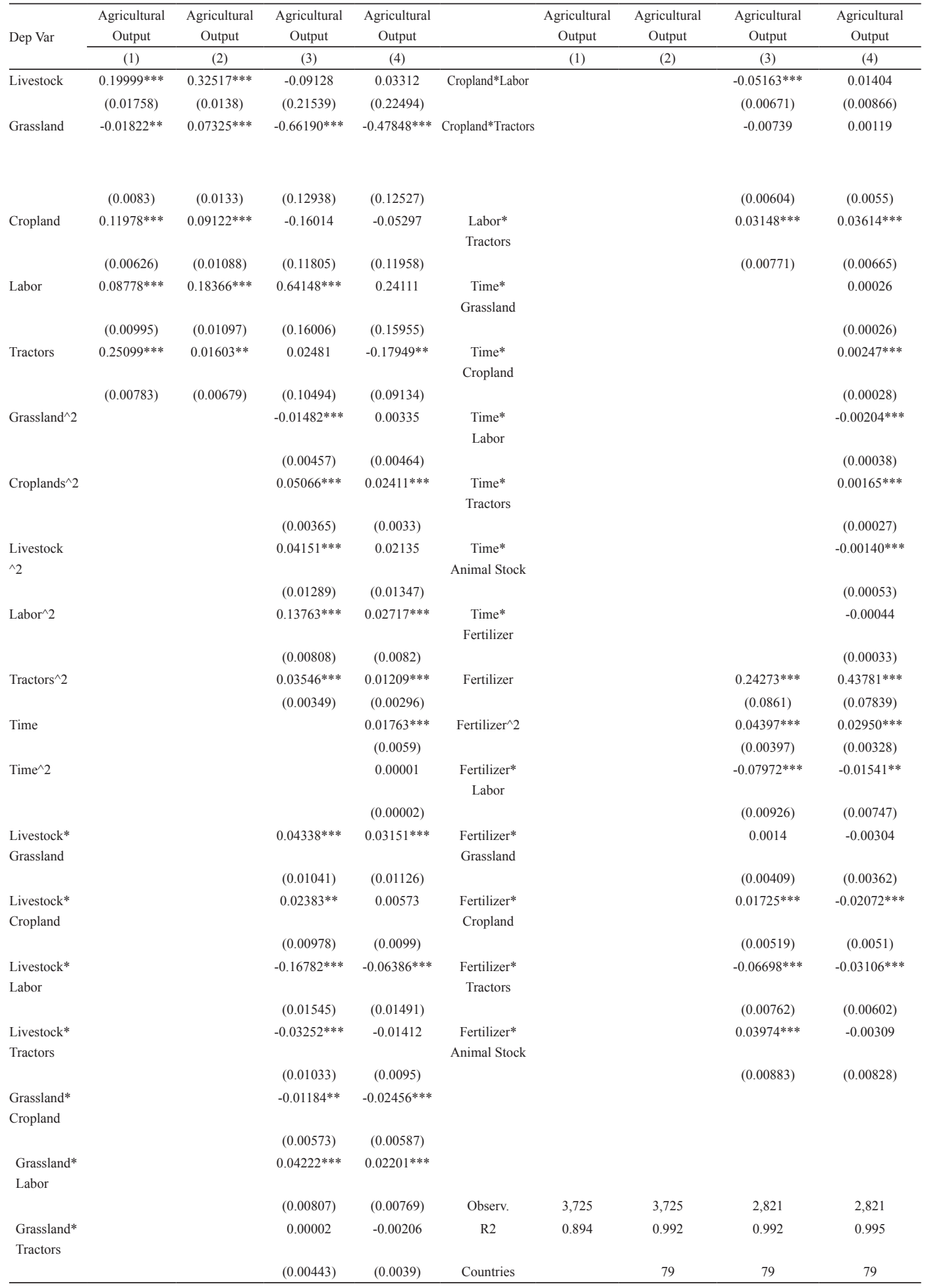

Robust Standard Errors are in parentheses. All variables are in logarithms $* * * \mathrm{p}<0.01, * * \mathrm{p}<0.05, * \mathrm{p}<0.1$ 
mates from the previous section. The explanatory variables of our estimates include credit as a share of GDP, the logarithm of electricity consumption, the logarithm of the number of telephone lines, the share of irrigated soil, the economy's trade openness measured as the percentage of exports and imports divided by GDP, the percentage of investment divided by GDP, relative total productivity with respect to the United States, the logarithm of years of education of the population that is over 15 years of age, and temperature anomalies by country in Celsius ${ }^{4}$.

Table A1 in the appendix shows the descriptive statistics that can be used to estimate the orders of magnitude of the effects found for each explanatory variable. Table 3 shows the results of the estimations of productivity growth determinants. The first five estimates use ordinary least squares (OLS) as the estimation technique, and the last four use instrumental variables (IVs). All estimates, except the last two, include country fixed effects, and estimates 4 to 7 include time fixed effects. All standard errors of the estimates are robust, and the IV estimates show the instrument validity F-test and the overidentification test.

Column 1 shows the impact of infrastructure variables, such as electricity consumption, telephony, irrigated land; and macroeconomic variables, such as trade openness, domestic credit, and investment. All variables except investment are significant at levels above $5 \%$ and positively impact agricultural productivity. Column 2 adds a measure of relative productivity to the previous variables with respect to the US and education. Relative productivity has positive and significant impacts, while education is insignificant. Column 3 adds temperature anomalies that are found to be insignificant, Column 4 adds temporal effects to the variables in Column 3, and Column 5 controls for positive temperature anomalies and temporal effects with all the variables included in regression model 3 . In this case, the only significant variables with positive effects are domestic credit, telephony, irrigation, openness, and relative productivity.

The regressions discussed thus far could be subject to endogeneity. In particular, variables such as education and trade openness, measured as the total of exports and imports divided by GDP, could be strongly affected by agricultural productivity. Thus, in Columns 6 and 7, we use instrumental variables as an estimation technique $^{5}$. In Column 6, credit, electricity, irrigation, openness, and relative productivity positively affect agricultural productivity and are statistically significant. Instrumental variables reveal that positive temperature anomalies negatively impact productivity. Column 7 disaggregates the effects of education and positive temperature anomalies in the high-income group and the rest of the countries using a high-income interactive dummy variable. This last estimate shows that credit, electricity, telephony, irrigation, openness, and relative productivity are statistically significant and positively affect agricultural productivity. Additionally, positive temperature anomalies are significant and negatively impact countries that do not belong to the high-income group and positively impact those that belong to the high-income group. Education negatively impacts high-income countries but positively and significantly affects the other countries. We focus on positive temperature anomalies inspired by the vast scientific literature that confirms the existence of global warming. A key point that we elucidate in these last exercises is whether rising temperatures are indeed detrimental to agriculture on average. Without prior assumption, our estimates reveal that positive temperature anomalies are detrimental to agricultural productivity on average. However, our result is an average, and some countries might have

\footnotetext{
4 In units of 0.01 degrees Celsius.

5 We use the lagged values of the endogenous variables as instruments, choosing a set that allows for an estimate with an exogeneity test and weak instruments that provide valid estimates.
} 
productivity that increases with positive temperature anomalies, whereas in other countries, productivity might decrease.

The regressions in Columns 8 and 9 are estimated without fixed effects in which the first does not have time effects and the second does to conduct a sensitivity analysis of the results and their explanatory power. Table 4 shows the explanatory power of the estimates in Columns 7 (with fixed and temporary effects) and 8 (without fixed or time effects). The first input for this analysis is to identify the average, maximum, and minimum TFP growth values. The average, maximum, and minimum are $1.7 \%, 3.1 \%$ and $-0.2 \%$ respectively. The standard deviation is $0.1 \%$ within each country. Therefore, it is prudent to consider how much of the variation within each country is explained by increases of one standard deviation in the independent variables, in this case $0.1 \%$. Lastly, it is worth asking what the predicted value of the estimates in the mean of each variable is and how it compares with the sample mean of $1.7 \%$. The values of the effects of the regressions' independent variables in Columns 7 and 8 assessed at the mean are $1.4 \%$ and $2.7 \%$, respectively. The effects of each variable are clearly overestimated in the regressions that do not control for fixed or time effects, while the estimates that do so predict an average value closer to the sample, and therefore explain the same variance within each country. Although the R2 (explained variance percentage) with instrumental variables cannot be clearly interpreted, they do not lose their ordinal properties. Thus, a higher R2 is considered to be better. The foregoing also favors the results of the estimates in Column 7 versus Column 8.

\section{Conclusions}

In this study, we have researched the evolution of the agricultural sector's total factor productivity for a group of countries that includes Latin American and other developing countries alongside developed countries. This stage of the study included many limitations of FAOSTAT's data, as the quality of the data and the continuity of the relevant series ranging from 1961 to 2015 have been reduced during the past two decades. In the second stage of this study, we investigated the relevance of different variables as potential determinants of productivity growth, which include infrastructure, macroeconomic variables, and variables related to climate change.

The best representation for the agricultural production function, as shown in Bravo-Ortega \& Lederman (2004), continues to be the translog function due to its flexibility, which ensures that consideration is given to the heterogeneity that different inputs have for different countries. The results of the research on productivity determinants show a significant number of factors that affect agricultural productivity; however, each factor's elasticity is small. Their impact fluctuates from figures lower than $0.01 \%$, as is the case for domestic credit and trade openness, up to $-0.08 \%$ for global warming, or $0.08 \%$ for electricity consumption. This should not lead to confusion regarding their cumulative effect over long periods of time. For example, decreasing or increasing the sample mean from $1.7 \%$ to $1.62 \%$ in a 50 -year period implies losing or gaining approximately 10 percentage points of TFP growth and, consequently, GDP growth. ${ }^{6}$ The impact of the global warming coefficient strongly depends on the potential scenarios. If, as estimated, the temperature in Chile rises 2 or 3 degrees Celsius by 2100 , it will be the most important factor that decreases agricultural productivity.

This study has several policy implications. First, the investment in public and private infrastruc-

\footnotetext{
${ }^{6}$ One should remember that the independent variables explain an annual 1.4\% TFP growth while the sample mean is $1.7 \%$. Consequently, the figures in our estimates explain a majority of the variation between countries and the TFP variance within a country; however, the latter is shown to be small.
} 
Table 3. Determinants of Agricultural Productivity Growth (1961-2017)-- Complete Sample

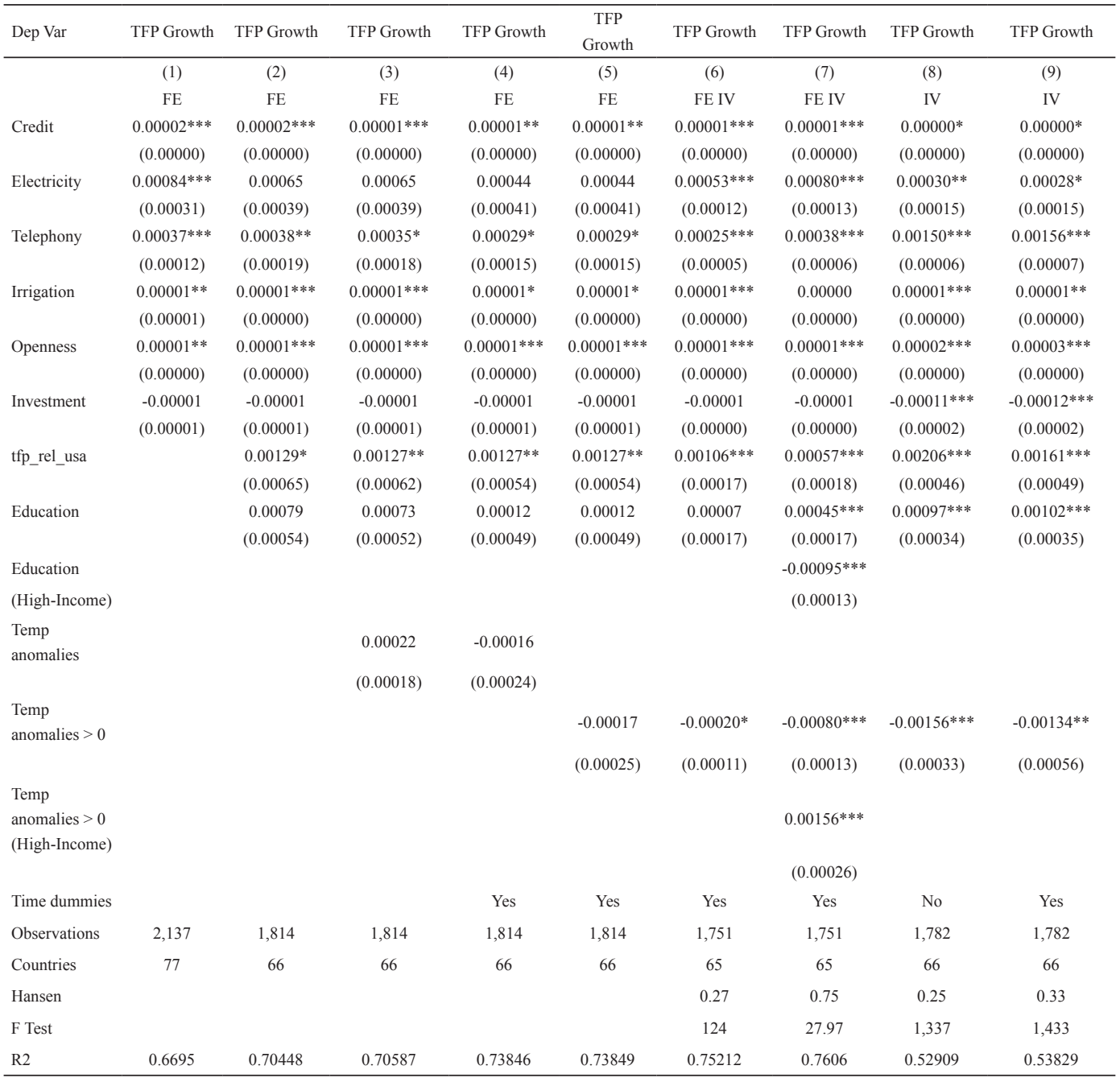

Robust Standard Errors in parentheses *** $\mathrm{p}<0.01, * * \mathrm{p}<0.05, * \mathrm{p}<0.1$

Table 4. Explanatory power of the estimated regressions. Complete Sample.

\begin{tabular}{|c|c|c|c|c|c|c|c|c|}
\hline \multirow[b]{2}{*}{ Variable } & \multirow[b]{2}{*}{ Mean } & \multirow[b]{2}{*}{ Within } & \multicolumn{3}{|c|}{$\begin{array}{c}\text { Regression (7) } \\
\text { FE and Time Effects }\end{array}$} & Regression (8) & \multicolumn{2}{|c|}{$\begin{array}{c}\text { No FE } \\
\text { No Time Effects }\end{array}$} \\
\hline & & & Coef & Within & $\begin{array}{l}\text { Mean } \\
{ }^{*} \text { Coef }\end{array}$ & Coef & Within & $\begin{array}{l}\text { Mean } \\
{ }^{*} \text { Coef }\end{array}$ \\
\hline & & S.D. & & S.D. * Coef & & & S.D. * Coef & \\
\hline Credit & 70.28 & 22.115 & $0.000 \%$ & $0.000 \%$ & $0.000 \%$ & $0.000 \%$ & $0.000 \%$ & $0.000 \%$ \\
\hline Posit Temp Anom & 0.69 & 0.255 & $-0.080 \%$ & $-0.020 \%$ & $-0.056 \%$ & $-0.156 \%$ & $-0.040 \%$ & $-0.108 \%$ \\
\hline Electricity & 7.85 & 0.331 & $0.080 \%$ & $0.026 \%$ & $0.628 \%$ & $0.030 \%$ & $0.010 \%$ & $0.235 \%$ \\
\hline Telephony & 15.22 & 0.652 & $0.038 \%$ & $0.025 \%$ & $0.578 \%$ & $0.150 \%$ & $0.098 \%$ & $2.283 \%$ \\
\hline Irrigation & 21.99 & 6.499 & 0.00000 & $0.000 \%$ & $0.000 \%$ & $0.001 \%$ & $0.006 \%$ & $0.022 \%$ \\
\hline Openness & 65.95 & 12.313 & $0.001 \%$ & $0.012 \%$ & $0.066 \%$ & $0.002 \%$ & $0.025 \%$ & $0.132 \%$ \\
\hline TFP Growth & $1.7 \%$ & $0.1 \%$ & Total Effect & $0.1 \%$ & $1.4 \%$ & Total Effect & $0.1 \%$ & $2.7 \%$ \\
\hline
\end{tabular}

Note: S.D. is the acronym for standard deviation. Coef corresponds to the estimated coefficient.

Within identifies the standard deviation within each country for the corresponding variable. Hi: corresponds to High-Income 
ture becomes important for productivity growth. Thus, irrigation, electrification and telephone infrastructure are important contributors to productivity growth. Second, trade openness is shown to be a relevant policy tool. Using additional data, future work should address the consequences of global warming and identify possible heterogeneity across countries to continue beyond the reported average effect. Similarly, the rich dataset compiled offers the possibility to estimate and compare results with alternative or complementary econometric techniques.

\section{Acknowledgements}

I would like to express my thanks for the comments and suggestions from María Emilia Undurraga, Alberto Valdés, Joseph Ramos, Jose Miguel Benavente and Patricio Riveros. This study has been commissioned by the Office of Agricultural Research and Policies (ODEPA), Ministry of Agriculture, Chile. All opinions contained in this work belong to solely the author and do not represent the Chilean government. I would like to acknowledge the excellent research support provided by Claudio Rojas and Rodrigo Miranda.

\section{Resumen}

C. Bravo-Ortega. 2021. Productividad en el sector agrícola: Una visión global desde una perspectiva latinoamericana. Int. J. Agric. Nat. Resour. 288-302. La productividad agrícola ha sido objeto de un intenso examen desde la época de Adam Smith. En este artículo, nos centramos en la productividad agrícola desde dos perspectivas. En primer lugar, proporcionamos estimaciones del crecimiento de la productividad total de los factores (PTF) para un panel de 79 países durante un período de aproximadamente 60 años. En segundo lugar, investigamos los posibles determinantes del crecimiento de la productividad, entre los que se encuentran las infraestructuras, las variables macroeconómicas y las relacionadas con el cambio climático. Descubrimos que la productividad varía mucho entre países, y que los principales países muestran un crecimiento anual de la productividad agrícola de entre el $2 \%$ y el 3\%. En cuanto a los determinantes de la productividad, encontramos pequeños efectos dentro de los países, pero importantes efectos entre ellos.

Palabras clave: Agricultura, datos de panel, productividad.

\section{References}

Alston, J.M., Beddow, J.M., \& Pardey, P.G. (2009). Agricultural research, productivity, and food prices in the long run. Science, 325(5945), 1209-1210.

Alston, J.M., Babcock, B.A., \& Pardey, P.G. (2010). The shifting patterns of agricultural production and productivity worldwide. Midwest Agribusiness Trade Research and Information Center.

Avila, A.F.D., \& Evenson, R.E. (2010). Total factor productivity growth in agriculture: the role of technological capital. Handbook of Agricultural Economics, 4, 3769-3822.

Avila, A.F.D., Romano, L., \& Garagorry, F. (2010). Agricultural productivity in Latin America and the Caribbean and sources of growth. Handbook of Agricultural Economics, 4, 3713-3768.

Bravo-Ortega, C \& Lederman, D. (2004). Agricultural Productivity and its Determinants: Revisiting International Experiences. Estudios de Economía, 31(2), 133-163.

Bustos, P., Caprettini, B., \& Ponticelli, J. (2016). Agricultural productivity and structural transforma- 
tion: Evidence from Brazil. American Economic Review, 106(6), 1320-65.

Coelli, T.J., \& Rao, D.P. (2005). Total factor productivity growth in agriculture: a Malmquist index analysis of 93 countries, 1980-2000. Agricultural Economics, 32, 115-134.

Domanska, K., Kijek, T., \& Nowak, A. (2014). Agricultural total factor productivity change and its determinants in European Union countries. Bulgarian Journal of Agricultural Science, 20(6), $1273-1280$

Fuglie, K., MacDonald, J.M., \& Ball, V.E. (2007). Productivity growth in US agriculture. USDAERS Economic Brief, (9).

Fuglie, K.O. (2008). Is a slowdown in agricultural productivity growth contributing to the rise in commodity prices? Agricultural Economics, 39, 431-441.

Gollin, D. (2010). Agricultural productivity and economic growth. Handbook of Agricultural Economics, 4, 3825-3866.

Hayami, Y., \& V. Ruttan (1985). Agricultural Development. An International Perspective. The Johns Hopkins University Press, Baltimore and London.

Huang, J., Hu, R., van Meijl, H., \& van Tongeren, F. (2004). Biotechnology boosts to crop productivity in China: trade and welfare implications. Journal of Development Economics, 75(1), 27-54.

Isaksson, A. (2007). Determinants of total factor productivity: a literature review. Research and Statistics Branch, UNIDO.

Kawagoe, T., Hayami, Y., \& Ruttan, V. (1985). The Intercountry Agricultural Production Function and Productivity Differences among Countries. Journal of Development Economics 19, 113-132.

Kim, H.Y. (1992). The Translog Production function and Variable Returns to Scale, Review of Economics and Statistics, 74(3), 546-52.

Lau, L., \& Yotopoulos, P. (1989). The Meta Production Function Approach to Technological Change in World Agriculture. Journal of Development Economics 31, 241-269.

Lio, M., \& Liu, M.C. (2006). ICT and agricultural productivity: evidence from cross-country data. Agricultural Economics, 34(3), 221-228.

Martin, W., \& Mitra, D. (2001). Productivity Growth and Convergence in Agriculture and Manufacturing, Economic Development and Cultural Change, 49(2), 403-21.

Nin Pratt, A., \& Yu, B. (2009). An updated look at the recovery of agricultural productivity in subSaharan Africa (No. 1005-2016-79084).

Po-Chi, C.H.E.N., Ming-Miin, Y.U., Chang, C.C., \& Shih-Hsun, H.S.U. (2008). Total factor productivity growth in China's agricultural sector. China Economic Review, 19(4), 580-593.

Restuccia, D., Yang, D.T., \& Zhu, X. (2008). Agriculture and aggregate productivity: A quantitative cross-country analysis. Journal of Monetary Economics, 55(2), 234-250.

Riveros, P. (2019). Evolución de la productividad silvoagropecuaria y una aproximación a sus determinantes. Oficina de Estudios y Políticas Agrarias -Odepa. Gobierno de Chile.

Ruttan, V. (2002). Productivity Growth in World Agriculture: Sources and Constraints. Journal of Economic Perspectives, 16(4), 161-184.

Seré, C., H. Steinfeld (1996). World livestock production systems. Current status, issues and trends. Food and Agriculture Organization of the United Nations, Rome.

Thirtle, C.S., \& Piesse, J. (2003). The Impact of Research Led Agricultural Productivity Growth on Poverty Reduction in Africa, Asia and Latin America. World Development 31(12), 19591975.

Trindade, F.J., \& Fulginiti, L.E. (2015). Is there a slowdown in agricultural productivity growth in South America? Agricultural Economics, 46(S1), 69-81. 


\section{Appendix}

Table A1. Descriptive Statistics -- Complete Sample.

\begin{tabular}{|c|c|c|c|c|c|c|c|c|}
\hline Variable & & Mean & St. Dev. & Min & Max & & & Observations \\
\hline \multirow[t]{3}{*}{ Credit (GDP \%) } & overall & 70.279 & 50.405 & 2.476 & 253.26 & $\mathrm{~N}$ & $=$ & 1,030 \\
\hline & between & & 46.516 & 4.399 & 196.33 & $\mathrm{n}$ & $=$ & 62 \\
\hline & within & & 22.115 & -17.288 & 159.23 & $\mathrm{~T}$ & $=$ & 17 \\
\hline Anomalies & overall & 0.695 & 0.344 & 0.000 & 1.41 & $\mathrm{~N}$ & $=$ & 1,030 \\
\hline \multirow{2}{*}{$\begin{array}{l}\text { Temperature } \\
\left(0.01{ }^{\circ} \mathrm{C}\right)\end{array}$} & between & & 0.246 & 0.246 & 1.10 & $\mathrm{n}$ & $=$ & 62 \\
\hline & within & & 0.255 & -0.101 & 1.47 & $\mathrm{~T}$ & $=$ & 17 \\
\hline Anomalies & overall & 0.097 & 0.266 & 0.000 & 1.41 & $\mathrm{~N}$ & $=$ & 1,030 \\
\hline Temperature & between & & 0.212 & 0.000 & 1.10 & $\mathrm{n}$ & $=$ & 62 \\
\hline Positive $\left(0.1^{\circ} \mathrm{C}\right)$ & within & & 0.176 & -0.323 & 1.03 & $\mathrm{~T}$ & $=$ & 17 \\
\hline Electricity & overall & 7.846 & 1.235 & 3.832 & 10.15 & $\mathrm{~N}$ & $=$ & 1,030 \\
\hline \multirow[t]{2}{*}{ (kwh per capita) } & between & & 1.335 & 4.401 & 10.02 & $\mathrm{n}$ & $=$ & 62 \\
\hline & within & & 0.331 & 6.572 & 9.51 & $\mathrm{~T}$ & $=$ & 17 \\
\hline Telephony & overall & 15.218 & 1.799 & 9.197 & 19.72 & $\mathrm{~N}$ & $=$ & 1,030 \\
\hline \multirow[t]{2}{*}{ (number of lines) } & between & & 1.901 & 9.584 & 18.73 & $\mathrm{n}$ & $=$ & 62 \\
\hline & within & & 0.652 & 12.281 & 18.25 & $\mathrm{~T}$ & $=$ & 17 \\
\hline \multirow{3}{*}{$\begin{array}{l}\text { Irrigation (land } \\
\text { percentage) }\end{array}$} & overall & 21.989 & 20.251 & 0.304 & 123.80 & $\mathrm{~N}$ & $=$ & 1,030 \\
\hline & between & & 20.481 & 0.316 & 83.59 & $\mathrm{n}$ & $=$ & 62 \\
\hline & within & & 6.499 & -16.562 & 96.84 & $\mathrm{~T}$ & $=$ & 17 \\
\hline \multirow{3}{*}{$\begin{array}{l}\text { Openness } \\
((\mathrm{X}+\mathrm{M}) / \mathrm{GDP} \\
(\%))\end{array}$} & overall & 65.954 & 35.367 & 9.100 & 220.41 & $\mathrm{~N}$ & $=$ & 1,030 \\
\hline & between & & 32.868 & 21.322 & 172.00 & $\mathrm{n}$ & $=$ & 62 \\
\hline & within & & 12.313 & 16.574 & 114.36 & $\mathrm{~T}$ & $=$ & 17 \\
\hline \multirow{3}{*}{$\begin{array}{l}\text { Investment } \\
\text { (GDP percentage) }\end{array}$} & overall & 22.469 & 5.229 & 6.756 & 45.51 & $\mathrm{~N}$ & $=$ & 1,030 \\
\hline & between & & 3.859 & 13.183 & 36.73 & $\mathrm{n}$ & $=$ & 62 \\
\hline & within & & 3.572 & 9.791 & 39.54 & $\mathrm{~T}$ & $=$ & 17 \\
\hline Productivity & overall & 0.705 & 0.248 & 0.139 & 1.62 & $\mathrm{~N}$ & $=$ & 1,030 \\
\hline \multirow[t]{2}{*}{ rel USA } & between & & 0.245 & 0.191 & 1.23 & $\mathrm{n}$ & $=$ & 62 \\
\hline & within & & 0.088 & 0.257 & 1.13 & $\mathrm{~T}$ & $=$ & 17 \\
\hline Education & overall & 2.102 & 0.362 & 0.077 & 2.58 & $\mathrm{~N}$ & $=$ & 1,030 \\
\hline \multirow[t]{2}{*}{ (Years) } & between & & 0.437 & 0.077 & 2.51 & $\mathrm{n}$ & $=$ & 62 \\
\hline & within & & 0.149 & 1.503 & 2.67 & $\mathrm{~T}$ & $=$ & 17 \\
\hline TFP growth & overall & 0.017 & 0.005 & -0.002 & 0.031 & $\mathrm{~N}$ & $=$ & 1,751 \\
\hline \multirow[t]{2}{*}{$(\% / 100)$} & between & & 0.006 & -0.001 & 0.029 & $\mathrm{n}$ & $=$ & 65 \\
\hline & within & & 0.001 & 0.012 & 0.020 & $\mathrm{~T}$ & $=$ & 26.9385 \\
\hline
\end{tabular}


Table A2. Agricultural productivity growth Translog Estimation (1961-2017).

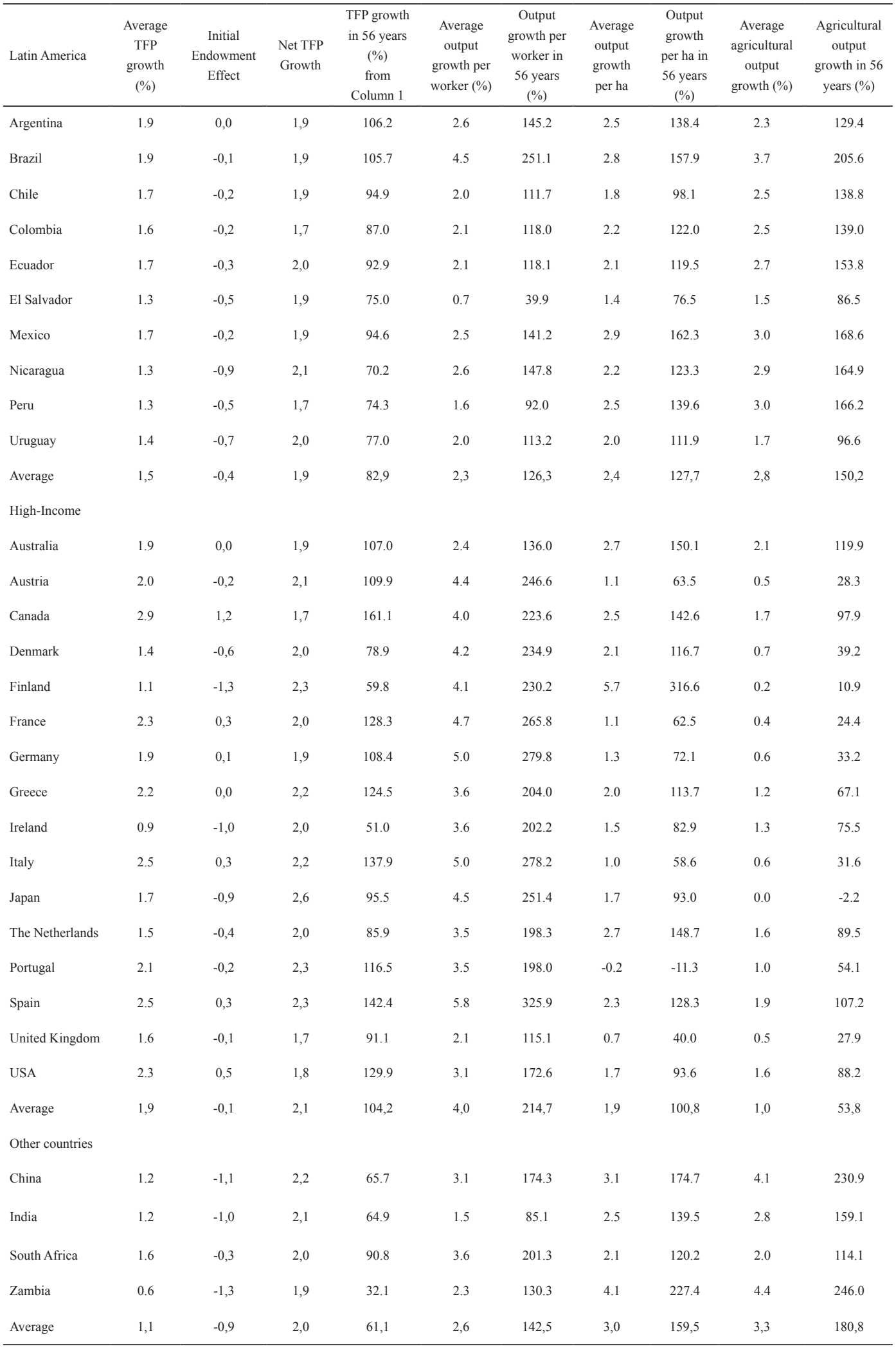


Table A3. Elasticities and returns to scale: Translog estimation (1961-2017).

\begin{tabular}{|c|c|c|c|c|c|c|c|}
\hline Latin America & Animals & Grassland & Cropland & Labor & Tractors & Fertilizers & Returns to scale \\
\hline Argentina & 0.49 & 0.09 & 0.17 & 0.14 & 0.05 & 0.02 & 0.95 \\
\hline Brazil & 0.38 & 0.12 & 0.24 & 0.21 & 0.02 & 0.09 & 1.07 \\
\hline Chile & 0.38 & 0.03 & 0.13 & 0.16 & 0.01 & 0.13 & 0.84 \\
\hline Colombia & 0.39 & 0.07 & 0.22 & 0.15 & 0.00 & 0.11 & 0.95 \\
\hline Ecuador & 0.36 & 0.02 & 0.25 & 0.14 & 0.00 & 0.09 & 0.86 \\
\hline El Salvador & 0.28 & 0.00 & 0.20 & 0.11 & 0.00 & 0.16 & 0.75 \\
\hline Mexico & 0.36 & 0.10 & 0.21 & 0.21 & 0.03 & 0.10 & 1.00 \\
\hline Nicaragua & 0.41 & 0.01 & 0.18 & 0.05 & -0.03 & 0.14 & 0.76 \\
\hline Peru & 0.35 & 0.06 & 0.18 & 0.17 & 0.02 & 0.11 & 0.89 \\
\hline Uruguay & 0.51 & 0.06 & 0.05 & 0.00 & 0.00 & 0.12 & 0.74 \\
\hline Average & 0.32 & 0.04 & 0.19 & 0.12 & 0.01 & 0.11 & 0.78 \\
\hline \multicolumn{8}{|l|}{ High-Income } \\
\hline Australia & 0.58 & 0.07 & 0.02 & 0.09 & -0.03 & 0.16 & 0.89 \\
\hline Austria & 0.35 & 0.00 & 0.08 & 0.13 & 0.04 & 0.13 & 0.73 \\
\hline Canada & 0.45 & -0.02 & 0.21 & 0.20 & -0.02 & 0.10 & 0.92 \\
\hline Denmark & 0.33 & 0.03 & 0.00 & 0.00 & 0.00 & 0.23 & 0.59 \\
\hline Finland & 0.25 & 0.05 & -0.02 & 0.00 & 0.05 & 0.22 & 0.54 \\
\hline France & 0.38 & 0.04 & 0.16 & 0.15 & 0.00 & 0.16 & 0.89 \\
\hline Germany & 0.33 & 0.06 & 0.11 & 0.14 & 0.02 & 0.18 & 0.84 \\
\hline Greece & 0.32 & -0.01 & 0.19 & 0.23 & 0.03 & 0.10 & 0.86 \\
\hline Ireland & 0.41 & 0.09 & -0.09 & -0.03 & 0.00 & 0.25 & 0.63 \\
\hline Italy & 0.31 & 0.02 & 0.23 & 0.23 & 0.04 & 0.09 & 0.91 \\
\hline Japan & 0.15 & 0.06 & 0.19 & 0.24 & 0.05 & 0.15 & 0.84 \\
\hline The Netherlands & 0.36 & 0.04 & 0.05 & 0.03 & 0.00 & 0.20 & 0.68 \\
\hline Portugal & 0.28 & -0.01 & 0.21 & 0.19 & 0.04 & 0.09 & 0.81 \\
\hline Spain & 0.34 & 0.00 & 0.23 & 0.25 & 0.02 & 0.10 & 0.94 \\
\hline United Kingdom & 0.41 & 0.07 & 0.03 & 0.07 & 0.00 & 0.21 & 0.78 \\
\hline USA & 0.45 & 0.09 & 0.12 & 0.18 & 0.00 & 0.17 & 1.00 \\
\hline Average & 0.28 & 0.05 & 0.21 & 0.20 & 0.03 & 0.09 & 0.85 \\
\hline \multicolumn{8}{|l|}{ Other Countries } \\
\hline China & 0.16 & 0.19 & 0.26 & 0.36 & 0.07 & 0.14 & 1.19 \\
\hline India & 0.15 & 0.19 & 0.34 & 0.22 & 0.07 & 0.11 & 1.08 \\
\hline South Africa & 0.42 & 0.08 & 0.10 & 0.17 & 0.02 & 0.13 & 0.91 \\
\hline Zambia & 0.30 & 0.09 & 0.07 & 0.17 & 0.05 & 0.13 & 0.81 \\
\hline Average & 0.29 & 0.04 & 0.21 & 0.12 & 0.02 & 0.10 & 0.80 \\
\hline World & 0.33 & 0.03 & 0.18 & 0.13 & 0.00 & 0.12 & 0.79 \\
\hline
\end{tabular}

